\title{
COMMON LANDS AND ECONOMIC DEVELOPMENT IN SPAIN*
}

\author{
FRANCISCO J. BELTRÁN TAPIA \\ University of Cambridge ${ }^{\mathrm{a}}$
}

\begin{abstract}
The impact of the privatisation of the commons remains a contested topic throughout the social sciences. Focusing on the Spanish case, this article reviews the literature and provides an overall assessment of this historical process based on recent research. Common lands appear to have been reasonably well managed and their dismantling did not foster agricultural productivity. Instead, the privatisation process negatively affected the economic situation of a large proportion of rural households and local councils, as well as deteriorating the stock of social capital. Therefore, the long-standing belief in the existence of a trade-off between equity and efficiency actually turns out to be misleading.
\end{abstract}

Keywords: common lands, privatisation, $19^{\text {th }}$ century, Spain

JEL Code: N53, N33, O10

\footnotetext{
* Received 24 November 2014. Accepted 20 July 2015. The author is extremely thankful for the comments received from Bob Allen, Domingo Gallego, Vicente Pinilla, Iñaki Iriarte, José Miguel Lana, Jane Humphries and James Simpson, as well as those from the editor and three anonymous referees. Financial support from the Spanish Ministry of Science and Education (Projects HAR2012-30732 and ECO2012-33286) is also gratefully acknowledged.

a Magdalene College, University of Cambridge, Magdalene St., Cambridge CB3 0AG, UK. fjb38@cam.ac.uk.
} 


\section{RESUMEN}

El impacto de la privatización de los comunales sigue siendo una cuestión controvertida dentro de las ciencias sociales. Centrándose en el caso español, este artículo revisa la literatura y ofrece una valoración global de este proceso histórico basado en investigaciones recientes. Las tierras comunales estaban razonablemente bien gestionadas y el desmantelamiento del régimen comunal no fomentó la productividad agrícola. El proceso privatizador, en cambio, afectó negativamente a la situación económica de una parte importante de las familias y de los ayuntamientos rurales, además de empeorar el stock de capital social. Por consiguiente, la extendida creencia en la existencia de una relación inversa entre eficiencia y equidad no resulta adecuada.

Palabras clave: comunales, privatización, siglo XIX, España

Oh! -he replied raising both arms simultaneously-, that, my friend, is this village's greatest wealth! That's the Common Field ... It belongs to each and every one of the village neighbours (Pereda [1895] 1999, p. 170, my emphasis).

In Peñas Arriba (1895), the celebrated $19^{\text {th }}$-century novel by José María Pereda, the character of Don Celso, a relatively prosperous farmer of a small village in north-western Spain, invites his nephew, Marcelo, who has spent most of his life in Madrid, to pay him a visit and get to know the place of origin of his ancestors. Without direct descendants and feeling that his days in this world are coming to an end, he secretly hopes that, after spending some time in the community, Marcelo will accept to become his heir and take over his estates. In the passage above, Don Celso, from the balcony of his house, offers his recently arrived nephew a panoramic view of the countryside surrounding the village, while casually explaining how the local economy functions. Pereda's appraisal of the commons above continues by describing how the common meadow was collectively harvested in August and, then, equally distributed among the neighbours in a sort of celebratory ritual. This event is described in more detail at the end of the novel where men and women alike gather together to work in a merry atmosphere (Pereda [1895] 1999, pp. 546-547). Despite the idealised description, this image conveys the importance that the local community attached to the commons not only in purely economic terms but also as the centre of socialisation ${ }^{1}$.

1 The positive view of the commons and its important role within the community is also tied to the structure of the novel itself, since the description of the commons takes place at the beginning of the novel, when the still immature young nephew arrives to the village, and the actual harvest of the 
This passage also reflects the distance between the liberal ideology dominating the commanding heights of the $19^{\text {th }}$-century Spanish economy and the wisdom of popular knowledge. Despite numerous warnings arising from every corner of the Iberian Peninsula, the dismantling of the communal regime was seen as the panacea that would unleash extraordinary productive forces in the countryside, as well as solve, as a byproduct, the financial difficulties of the Treasury. Gaspar Melchor de Jovellanos, the prestigious agricultural reformer of the last third of the $18^{\text {th }}$ century, rhetorically wonders in his well-known Informe sobre el Expediente de Ley Agraria: "What a spring of wealth will this decision alone not open, if subdued to the private property such vast and fecund territories, the action of the individual interest was then exercised [...]?» (1795, p. 21). The belief that the communal regime was an archaic and inefficient institution was not exclusive to Spanish elites but was shared throughout Europe. Jovellanos was actually advocating to mimic what was happening in Britain via the Parliamentary Enclosures and what was about to happen elsewhere in continental Europe (Robledo 1993; Clark 1998; Demélas and Vivier 2003). Arthur Young, for instance, the influential English agronomist, was eagerly championing the advantages of enclosure at roughly the same time (Allen 1982; Allen and O'Grada 1988) ${ }^{2}$. Jovellanos' vision though was not implemented immediately. Almost one hundred years later, in 1872, the Spanish Ministry of Development bitterly complained that the communal regime still constituted a harmful tradition that hampered the realisation of the nation's full economic capacity (Sanz Fernández 1985, p. 218). The weakness of the Spanish Liberal Party and the conflicts presiding over most of the first half of the $19^{\text {th }}$ century prevented the privatisation of the commons from taking place earlier. However, as soon as the liberal government felt itself secured in office, the General Disentailment Act (1855) was quickly passed, forcing local councils to sell their commons through public auctions. Policy and ideology went closely hand in hand. Echoing liberal advocates from all over the continent, Fermín Caballero, a prominent agricultural reformer writing at the height of the privatisation process, regards the commons as "the worst agricultural illness, the cancer corroding its heart» $(1864, \text { p. 121) })^{3}$.

Hence, it is no wonder that, given this inheritance, traditional historiography has positively regarded the privatisation of the communal regime as a precondition to foster economic growth ${ }^{4}$. This line of enquiry argues that

(footnote continued)

common meadow takes place in the last chapter when all the intricacies of the plot have been resolved and a now mature character decides to stay in the village permanently and take over his uncle's patrimony.

2 For a detailed account of the pro-enclosure atmosphere in $18^{\text {th }}$-century Britain, see Enrle (1961). (2014)

On the characterisation of the commons present in the Spanish liberal ideology, see also Lana

4 See, for instance, Chambers and Mingay (1966) and North and Thomas (1978). Allen (1992) devotes the term "agrarian fundamentalism» to the proponents of this view, who also defend the efficiency of large-scale farms. For the Spanish case, see Herr (1974). 
private property rights are required in order to trigger investment and innovation and, also, that common property regimes lead to overexploitation. The negative image surrounding the communal regime was most influentially put forward by Garret Hardin's portrayal of the «tragedy of the commons» ${ }^{5}$. According to Garret Hardin, «individuals locked into the logic of the commons are free only to bring on universal ruin» $(1968$, p. 1248). However, starting in the 1980s, a growing literature examining historical and contemporary commons has shown that common property regimes can be efficient and sustainable, thus casting doubt on previous interpretations and revaluating the role that common resources had for the local communities that managed them ${ }^{6}$. For these authors, what is essential is not whether property rights are private, public or communal but whether they are properly defined and enforced ${ }^{7}$.

The transition to modern economic growth nonetheless remains one of the most researched and controversial fields in economic history ${ }^{8}$. In particular, the explanation that linked the enclosure of the commons with the British agricultural revolution has been confronted by Robert Allen's work, which defends that not only was the agricultural revolution already on its way long before the Parliamentary enclosures, but also that agricultural productivity growth had also taken place on open fields (Allen 1992, 1999, 2001, 2003). Although agricultural productivity has been the main yardstick against which the privatisation of the commons has been evaluated, the distributional consequences of this process have also been considered (Humphries 1990; Neeson 1993). The lower rural classes, dispossessed of their customary rights on the commons, suffered a decline in living standards and, unable to make a living in the countryside, were forced to join the urban labour force. However, in the light of the recent reassessment of the effect of enclosures on agricultural productivity mentioned above, the traditional view regarding the existence of a trade-off between equity and efficiency might have been misplaced.

This long-standing debate has been mostly fed by assessments of the British experience. Displacing the lens of the economic historian to other areas is especially relevant because, as mentioned above, the «successful» English example was followed by agricultural reformers across continental Europe (Clark 1998; Demélas and Vivier 2003). Despite being a crucial component of the organic-based Spanish pre-industrial economy, the

\footnotetext{
${ }^{5}$ See also Alchian and Demsetz (1973).

${ }^{6}$ Allen (1982, 1992), Runge (1986), Feeny et al. (1990), Ostrom (1990), Wade (1994), Baland and Platteau (1998, 2003), Clark (1998), Van Zanden (1999), De Moor et al. (2002), Besley and Ghatak 2009, De Moor (2009) and Fenske (2014), among others. Specific references to the Spanish case can be found throughout the text.

7 For recent developments within this line of enquiry, see Ostrom $(2005,2010)$ and Cole and Ostrom (2011).

8 See, for instance, the review of Floud and Johnson (2004), The Cambridge Economic History of Modern Britain, by D. McCloskey in the Times Higher Education Supplement (15 January 2004).
} 
FIGURE 1

COMMON LAND PERSISTENCE IN SPAIN, 1860-1930

(PERCENTAGE OF THE TOTAL AREA)

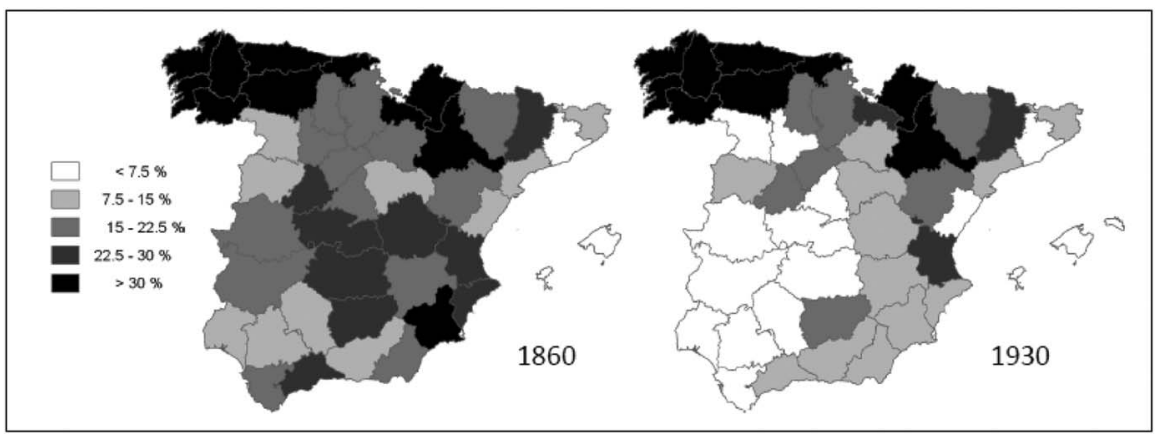

Source: Artiaga and Balboa (1992), GEHR (1994) and Gallego (2007). No data for the Basque country are available.

emergence of a new liberal state and the transformations brought about by the transition to capitalism triggered the gradual dismantling of the commons (Iriarte 2002; Beltrán Tapia 2015a) ${ }^{9}$. Although during the first half of the $19^{\text {th }}$ century the liberal state limited itself to establishing a legal framework that allowed municipalities to freely dispose off their commons, the General Disentailment Act (1855) forced municipalities to sell their lands via public auctions. The private appropriation of collective resources was not only carried out via legal means but also through illegal usurpations and appropriations. The magnitude of this process was enormous: around 20 per cent of the total land ended up being privatised during this period (Rueda 1997) ${ }^{10}$.

What makes the Spanish case especially interesting is that, despite following a similar path to other European countries, including England with its well-known enclosures, the importance of the privatisation process was geographically diverse (see Figure 1). While some regions completely dismantled the communal regime, others managed to preserve a large stock of common lands (GEHR 1994). Generally speaking, privatisation was more intense on the plains of central and southern Spain where an arid climate coexisted with a concentrated settlement pattern and a highly unequal land ownership structure. Without completely ruling out the importance of demographic and/or market-based pressures, the regional variation in the

\footnotetext{
9 For detailed summaries of the privatisation process, see also García Sanz (1985), Sanz Fernández (1985), López Estudillo (1992), Balboa (1999) and Jiménez Blanco (2002).

${ }^{10}$ In 1860, the commons represented more than one quarter of the total Spanish territory, a figure that would have been higher at the end of the $18^{\text {th }}$ century.
} 
intensity of the privatisation process is, however, better explained by the social and environmental contexts that shaped these rural communities (Beltrán Tapia 2015a).

The geographical differences in the intensity of privatisation turn the Spanish experience into an ideal subject of study for examining the consequences of this process. A growing body of research, mostly based on regional case studies, finds that the communal regime was compatible with economic development (Iriarte 1998; Moreno 1998; Serrano 2005; Lana 2008). Similarly, Lana (2014) also recently stresses that the persistence of the commons, far from being detrimental, may have fostered long-term economic development. This article reviews the literature on this issue and provides an overall assessment of this process based on recent research.

Common lands in Spain referred to lands that were either collectively owned by the constituents of a particular local authority or council or owned by the state (or the Crown) but actually left in the hands of the village community for their management and use ${ }^{11}$. Although common lands were mostly pastures, woodland and wasteland, part of these lands could also be broken up and used as arable land. Importantly, the communal regime in Spain involved two main types of access to the land. On the one hand, the user-rights over parts of the commons, referred to as propios, were temporarily rented out to particular individuals in exchange for a monetary income, thus constituting an important source of revenue for local councils. On the other hand, every member of the community had individual use-rights on the remaining village commons, referred to as comunales. Access to these resources, however, was not always free and was carefully regulated by a complex set of rules securing a relative equity of access and the resources' sustainability. Usually written down in the form of ordinances or bylaws, the rules that governed the use of the commons included limits on the type and number of animals that could be sent to the common pastures or the amount of timber, firewood or charcoal that villagers could collect from their woodlands ${ }^{12}$. Alternatively, the commons (kitchen gardens, meadows or arable land) were frequently divided into lots (suertes) and distributed among the village neighbours. These plots were individually held during a certain period and then returned to the community, which could then

11 For detailed descriptions of the functioning of the commons in Spain, including the rules and norms that regulated their use, see Nieto (1964), Mangas Navas (1981), Sanz Fernández (1985, 1986), Behar (1986), Linares (1995; 2001), Costa (1898), Iriarte (1998, 2002), Moreno (1998, 2002), Balboa (1999), Jiménez Blanco (2002), Serrano $(2005,2014)$ and Lana (2008).

12 A sort of hierarchy of grazing rights was sometimes also in place: while the best meadows were reserved for the working animals, the flocks of sheep and goats grazed in the poorer areas and woodland pastures (Behar 1986, p. 215). 
allot them again ${ }^{13}$. Other regulations and limitations, such as the season of the year the common pastures could be accessed or the periods when access was forbidden, the obligation of keeping the distributed plots cultivated or the prohibition on breaking up meadows into arable land, were also often in place. This set of norms and regulations indeed became more intricate, so as to avoid overexploitation, as pressure on these resources increased.

The rural communities, represented by local councils or municipalities, were responsible for designing and enforcing the rules and customs that regulated the use of the commons. Peer-monitoring mechanisms ensured the well functioning of the system but, if required, a guard was hired by the village to watch over the correct use of the commons ${ }^{14}$. Numerous examples from local ordinances show how fines rose exponentially with the importance of the offence or when reoffending. Apart from formal sanctions, reputation mechanisms were in place. As Behar (1986, p. 202) points out, to be caught cheating on the commons "was one of the greatest shames that could befall an adult member of the community».

By keeping transactions costs relatively low, this institutional design seems to have mitigated the problems usually associated with the management of the commons, namely negotiating agreements and monitoring and enforcing such agreements (Baland and Platteau 1998, 2003). The communal system was obviously not free from conflicts and it actually mirrored the problems of the society in which they were immersed (Balboa 1999; Jiménez Blanco 2002). Although the norms and rules implemented surely benefited the local notables, these institutions ensured that the interests of the lessfavoured groups were also preserved. Being the result of a centuries-long development, the extraordinary resilience of these institutions lay in their ability to solve the free rider problem and sustained local cooperation through a set of regulations operated at the local level and compatible with the social and environmental context in which they were enmeshed (Beltrán Tapia 2012, pp. 514-515).

The commons in Spain thus somewhat fulfilled the design principles that Elinor Ostrom (1990) established for an efficient management of common pool resources: formal and informal regulations defining who is entitled to

13 The duration of this period varied widely depending on the type of common involved: from short periods of 1 to 3 years to longer ones ranging from 12 to 20 years or even for a lifetime (Costa 1898, pp. 340-389; Behar 1986, pp. 227-229; Serrano 2014, p. 112). In Llávanes, a village in northern Spain, communal grain fields were distributed every 12 years. According to Behar, this "twelveyearly circulation ... was infrequent enough to give every vecino the time to cultivate his plot with care and frequent enough to keep them from losing their original character as commons» (Behar 1986, p. 229). The duration of the period was also influenced by the need to preserve the soil quality: once the land was returned to the community, it was then used as common pasture so as to replenish its nutrients (Costa 1898, pp. 265, 355).

14 The ordinances often established rewards to those discovering cheaters. In Santa María del Monte, for instance, a Leonese village, someone caught carrying more wood than the allowed quota will «pay twenty reales and half will go to the one who catches him» (Behar 1986, p. 247). 
use the commons and what (and how much) can be extracted from them; assemblies of users participating in devising those rules which are therefore adapted to local conditions; and monitoring and enforcing mechanisms guaranteeing that user-rights are appropriately enjoyed and those who violate the rules adequately sanctioned. There is indeed considerable evidence showing that the Spanish communal system was flexible enough to successfully adapt to changing circumstances ${ }^{15}$.

\section{III}

As seen in the first section, however, $19^{\text {th }}$-century reformers had a completely different picture of the role of the commons. Could it then be the case that, despite being a crucial element in the functioning of these rural economies and being reasonably well managed, privatisation had still been beneficial as its proponents so eagerly championed? The evidence I have gathered elsewhere, based on the econometric analysis of regional data between 1860 and 1930, does not support their views. First, the commons were not detrimental to agricultural development. The different stock of common lands does not explain the differences in the levels of agricultural productivity between Spanish provinces during the period 1900-1930 (Beltrán Tapia 2015c). Although privatisation may have fostered output per worker by bringing more land into cultivation, the loss of the commons reduced the availability of fertilising materials and working animals, thus counteracting that effect ${ }^{16}$. By sustaining livestock density, the commons were not only supplying the agricultural system with manure but also with a much needed draught power. Moreover, the commons also directly provided organic fertilisers obtained from the decomposition of different varieties of fern, a crucial feature of agriculture in north-western Spain (Balboa and Fernández Prieto 1996). These results show that these communal resources were actually a crucial element of a system in which agricultural activity was completely integrated with cattle breeding and forestry ${ }^{17}$.

However, given that the dismantling of common lands was a measure that «touched almost every aspect of social and economic life» (Tortella 2000, p. 51), the impact of privatisation on economic development should not only

15 See, for instance, Behar (1986), Moreno (1998), Iriarte (1998), Lana 2008) and Serrano (2005, 2014).

16 A detailed picture of these trends is presented in González de Molina et al. (2014). Moreover, the expansion of arable land could also have been carried out under a communal regime. This was actually the case in some areas. See, for instance, Behar (1986, pp. 229-241), Iriarte (1998, p. 135), Balboa (1999, p. 113), Linares (2001, p. 43) and Serrano (2005, p. 445; 2014, pp. 112-114).

17 Although not addressed here due to the lack of systematic evidence, the dismantling of this integrated organic economy may also have undermined the sustainability of the different ecosystems. On these environmental issues, see Guzmán and González de Molina (2006) and González de Molina et al. (2014). 
be examined in terms of agricultural efficiency, but also regarding its effects on a wider array of economic outcomes. On the one hand, the commons constituted an important source of complementary income for rural households. Apart from pasture to support livestock, they provided firewood for heating and cooking, not to mention the possibility of cropping on plots that were allocated among the locals ${ }^{18}$. These services, especially important for the lower part of the income distribution, were not subject to market mechanisms, so quantifying their effect in terms of wages or income per capita constitutes a hazardous task. Instead, the potential impact of these collective resources on standards of living can be assessed using measures of biological living standards. The persistence of these collective resources was indeed related to higher life expectancy and height, particularly during the second half of the $19^{\text {th }}$ century (Beltrán Tapia 2015b). The commons thus provided a crucial nutritional complement that helped to achieve higher levels of caloric intake but, most importantly, higher levels of animal proteins, mainly meat and dairy products ${ }^{19}$.

On the other hand, during the $19^{\text {th }}$ century, municipalities were responsible for the provision of elementary education and their financial capacity was crucial when it came to funding schooling expenditures. The monetary income derived from the cession of user-rights on the commons constituted a fundamental component of the municipal budget and the dismantling of the communal regime negatively affected local finances and the provision of public goods. In this regard, the persistence of common lands contributed positively to achieving significantly higher levels of both schooling expenditures and literacy rates (Beltrán Tapia 2013). By supporting municipal revenues, these collective resources sustained the local supply of education ${ }^{20}$. The provision of other public goods and services, such as medical care and poor relief, was surely also affected by privatisation (Bernal 1978; Iriarte 2003; Linares 2006). The loss of the commons also led municipalities to raise local taxes to compensate the subsequent decline in revenues (Moral Ruiz 1984; García and Comín 1995; Linares 2006). Given the regressive nature of a fiscal system mostly built around the taxation of consumption goods, this measure especially affected poorer households ${ }^{21}$.

18 The commons were also a source of a wide range of products, such as herbs, mushrooms, honey, wax, esparto, fish and game, among others, which could have a significant impact on the livelihood of poorer households (Serrano 2014, p. 115).

19 González de Molina et al. (2014, pp. 77-80) show that, even in places where the liberal reform did not involve an extreme concentration of land ownership, the loss of spontaneous pastures and forests, and the subsequent reduction of livestock numbers, significantly affected the availability of meat and dairy products and, in turn, the biological living standards of the population.

20 Beltrán Tapia (2013, pp. 505-506) also shows that the commons, by supporting households' incomes, also sustained the demand for education, especially during the second half of the $19^{\text {th }}$ century, which was a difficult period for the lower half of the population.

21 On the regressive nature of the Spanish fiscal system and the oligarchic system that sustained it, see Moreno Luzón (2007) and Comín and Yun-Casalilla (2012). 
Finally, the dismantling of collective practices attacked the social fabric that knitted the community together by negatively affecting the possibility of resorting to cooperation mechanisms different from the market. The institutions formed around the use and management of collective resources provided dense networks of continuous social interactions that facilitated the diffusion of information and the building of mutual knowledge and trust, which favoured cooperative behaviour. The analysis of the emergence of agricultural cooperatives during the early $20^{\text {th }}$ century indeed evidences that the fraction of the rural population involved in agricultural cooperatives was higher in those areas where the prior stock of collectively managed resources was also higher, pointing to the importance of these institutions for promoting social capital (Beltrán Tapia 2012).

\section{IV}

Contrary to what contemporary liberal thinkers and those who drank from such sources later on defended, the persistence of the commons in some Spanish regions was therefore not detrimental to economic development, at least relative to the institutional arrangements that succeeded them. On the contrary, during the early stages of modern economic growth, not only did the communal regime not limit agricultural productivity growth, but it indeed constituted a crucial part of the functioning of the rural economies in a number of ways. On the one hand, these collective resources complemented rural incomes and, subsequently, sustained households' consumption capacity. The reduction in life expectancy and heights in the provinces where privatisation was more intense, as well as the negative effect on literacy levels, strongly supports the idea that the privatisation of the commons deteriorated the living standards of a relatively large part of the population. On the other hand, the communal regime also significantly contributed to financing the municipal budget. Deprived of this important source of revenue, local councils became unable to adequately fund local public goods and ended up increasing local taxes. Finally, the dismantling of the commons deteriorated the social glue that held these rural communities together. All things considered, the persistence of the commons in some regions provided peasants with cooperation mechanisms different from the market and made the transition to modern economic growth more socially sustainable. Hence, the long-standing belief in the existence of a trade-off between equity and efficiency appears to be utterly misleading.

In this regard, Robert Allen's $(1982,1992,2001)$ conclusion that enclosing the commons allowed British rural elites to redistribute in their favour part of the existing agricultural surplus, rather than significantly increasing it, can also be applied to the Spanish case ${ }^{22}$. Notwithstanding other factors, the

22 Rephrasing this author, the majority of Spanish men and women would have been better off had the privatisation of the commons never occurred. For the original, see Allen (1992, p. 21). 
importance of the distributional conflicts surrounding institutions, rather than efficiency considerations, to explain their persistence or their demise is especially relevant here (Ogilvie 2007, pp. 662-665) 23 $^{23}$ The privatisation of the commons, especially after the Disentailment Act of 1855, was indeed much more intense in those regions where access to land was less equally distributed (Beltrán Tapia 2015a). The dismantling of the communal regime contributed to consolidating an unequal land structure at the expense of poor farmers and peasants (Gallego et al. 2010, pp. 94-100). Although the commons appear to have been a relatively efficient institution for a sizeable share of the population, large landowners accelerated their dismantling in order to lay their hands on a greater share of the economic pie ${ }^{24}$. The attack on the commons had to be obviously more subtle. It is, however, telling that the arguments that, from the late $18^{\text {th }}$ century and throughout the $19^{\text {th }}$ century, were advanced regarding the supposed inefficiency of the communal regime came mostly from representatives of the upper classes. According to Tomás y Valiente (1978, pp. 15-16), the main aim behind the General Disentailment Act was to benefit those who had the means to buy the disentailed property ${ }^{25}$. The landowning elite controlled the political power and, as in other European countries before, was able to pass the legislation, which best served their interests ${ }^{26}$. These aims were nonetheless masked under an elaborate rhetoric praising its potential benefits for the nation's welfare.

If common lands were not a primitive and relatively inefficient institution, we would therefore need to look elsewhere to explain Spanish agricultural backwardness ${ }^{27}$. This is, however, not to say that privatisation was necessarily negative per se but that the timing of the process and the way it was carried out had negative consequences on different economic and social dimensions. The effect of enclosure actually depended on the context in which it was applied ${ }^{28}$. The economic, social and environmental

23 A similar distinction between "class efficiency» and "productive efficiency» can be found in the study by Bhaduri (1991). Echoes of the idea that private property regimes or market institutions did not arise spontaneously but had to be actively promoted also resonate here (Polanyi 2001).

${ }^{24}$ In Extremadura, western Andalusia and some regions of central Spain, the privatisation of common lands was one of the keys to the property accumulation carried out by the local elites (GEHR 1994, p. 120). In doing so, the landowning elite employed all available means, legal or illegal (Cendrero 2014).

25 See also Simón Segura (1973, p. 295).

26 See Fontana (1973, pp. 161-165) and Gallego et al. (2010, pp. 99-100). For recent assessments of the Spanish political system during this period, see Moreno Luzón (2006) and Curto-Grau et al. (2012)

27 Although the agricultural sector has been traditionally blamed for the poor Spanish economic performance during the $19^{\text {th }}$ century, the current consensus contends that farmers were capable of adopting innovations but the low demand arising from the manufacturing and urban sector was unable to create the incentives to do so. The slow growth of Spanish agricultural productivity remains nonetheless a controversial topic. For recent approaches to these issues, see Simpson (1995), Pujol et al. (2001), Carmona and Simpson (2003), Pinilla (2004) and Clar and Pinilla (2009).

28 On the importance of the wider context for analysing the impact of institutional change, see Chang (2011). 
framework of each rural society determines the benefits and the costs of these changes; so it becomes a key factor to understand their impact. In this regard, the social and institutional context becomes especially important because it influences the parties that benefit from these transformations. Where large landowners prevailed, privatisation was more intense and it was carried out at the expense of the lower ranks of the rural population, whose living standards deteriorated. The distributional effects of privatisation should not be taken lightly. As it has been repeated often, the Disentailment missed the chance to reform the unequal structure of land property, especially in some regions ${ }^{29}$.

In addition, the potential benefits of privatisation may not be fully achieved unless the economy has reached a certain level of development. A modernising agriculture requires not only financial resources, but also sufficient economic incentives to carry out those investments. Even if private property rights provided better incentives, the low levels of income per capita, together with the unequal land property structure characteristic of $19^{\text {th }}$-century Spain, may have prevented that enclosure led to a more widespread adoption of modern agricultural techniques ${ }^{30}$. Moreover, bringing more land into cultivation at the expense of the commons during the $19^{\text {th }}$ century was surely going to run into diminishing returns due to the impossibility of resorting to chemical fertilisers and mechanisation to compensate the loss of organic fertilisers and working animals ${ }^{31}$.

Finally, the negative impact of the dismantling of the communal regime can only be limited if either a wide array of market opportunities exists or a new set of institutions is built to substitute the functions that the commons fulfilled for the local community. On the one hand, urbanisation and industrialisation only began to generate significant non-agricultural employment opportunities from the late $19^{\text {th }}$ century onwards ${ }^{32}$. On the other hand, the public sector was unable or unwilling to intervene and prevent, or even correct, the negative consequences that were likely to result from this process ${ }^{33}$. While state intervention in public health or primary schooling only started slowly during the first decades of the $20^{\text {th }}$ century,

${ }^{29}$ In this issue, see Carrión (1932), Malefakis (1970), Simón Segura (1973) and Costa (1898). Spanish liberalism, however, never seriously considered reforming land ownership distribution. This type of agrarian reform had to wait until the advent of the II Republic (1931-1936). See Robledo (1993).

30 The idea that the low urbanisation rates, scant manufacturing activity and poor income levels prevalent in the Iberian Peninsula during the $19^{\text {th }}$ century did not provide the adequate economic incentives to trigger a rapid modernisation of the agricultural structures is commonplace. In this issue, see also the references in footnote 24 .

31 This is especially relevant in the case of small- and medium-sized farms.

32 For the inability of cities and industrialising areas to attract rural workers in larger numbers, see Silvestre (2005). For the financial difficulties of the liberal state and its lack of concern regarding poor relief, see García and Comín (1995) and Comín (1996).

33 Potential effects that were nonetheless perfectly known by those implementing these reforms. The parliamentary discussions regarding this issue and the numerous warnings that the 
privatisation weakened local institutions, which became incapable of providing basic public services and were also forced to increase the tax burden. In this regard, the positive effect of the surviving common lands on biological living standards and educational attainments is especially strong during the second half of the $19^{\text {th }}$ century and decreases during the early $20^{\text {th }}$ century as the public sector began to intervene in those spheres (Beltrán Tapia 2013, 2015b).

The outcome of the privatisation process would surely have been different if Spain had been a more advanced economy, land had been more equitably distributed, the central government had provided local councils with alternative reliable sources of funding to replace the revenues previously obtained from the commons and/or the public sector had stepped in to fulfil the functions that were provided by these collective resources. In any case, instead of considering private, public and collective arrangements as mutually exclusive, it is more useful to consider them as complementary. In complex socio-ecological systems, institutional diversity indeed becomes an end in itself (Ostrom 2005, p. 256). In this regard, privatisation processes often eliminate the institutions that support a market economy, especially in developing regions where market failures are widespread and the state is absent (Timmer 2002, p. 1490). The social cohesion and social networks that the commons generated served as a complement to the market by providing certain basic services, such as credit access, diffusion of information, mutual assistance and a kind of social security net (Gallego 2007, pp. 168-169). In addition, the welfare of peasant families and their capacity to take advantage of the opportunities that were opening up depended on the whole array of assets that they could rely on (Ibid., 2007, p. 165) ${ }^{34}$. The dismantling of the communal regime undoubtedly reduced their room for manoeuvre and their capacity to successfully participate in market exchanges, either in the land, labour or capital markets ${ }^{35}$.

As Sheila Ogilvie (2007, p. 668) forcefully argues, any particular institution plays different roles and these activities are not usually separable. The overall efficiency of an institution cannot thus be properly assessed by simply focusing on its most visible feature and the effect of any institutional change

\footnotetext{
(footnote continued)

disentailment process provoked are well documented (Simón Segura 1973; Moral Ruiz 1979; Gómez Urdáñez 2002).

34 Apart from access to the commons, the rural households' room for manoeuvre was shaped by the level of access to other resources, such as land or credit, the possibility of obtaining alternative incomes (wages, sales or remittances) and the cohesion of local and familiar networks.

35 The efficiency of the market depends on the room for manoeuvre of those participating in the exchange (Bhaduri 1986).
} 
needs to be addressed by looking at all the different dimensions that might be affected by it. Positive consequences on one domain might be more than offset by its impact on other realms of the economic and social body. The commons in Spain were definitely a multifaceted institution. Although I have attempted to honour this claim and analyse this institutional change in all its complexity, other potential links between the dismantling of the communal regime and economic development have remained unexplored. As argued below, however, these absences do not significantly alter the picture drawn here.

On the one hand, it is usually argued that the British enclosures led to increasing inequality (Humphries 1990; Allen 1992; Neeson 1993) ${ }^{36}$. Spanish historiography has also long defended that the dismantling of the communal regime especially affected the living standards of the lower part of the rural population and accentuated existing inequalities ${ }^{37}$. Drawing on a multitude of local studies, the consensus is that privatisation reinforced the prior land ownership structure (Rueda 1997; Jiménez Blanco 2002). Where access to land was relatively widespread, broad layers of the rural population benefited from privatisation. Where inequality was high, large landowners took advantage of their privileged position to monopolise the sales which, in turn, promoted even more land concentration. Although a high level of inequality was conventionally thought to be behind higher rates of savings and investments and thus promoting economic growth, mounting research, both theoretical and empirical, now stresses the negative effects of inequality on economic development ${ }^{38}$. The unequal distribution of land ownership has in fact been considered as one of the main causes of the poor performance of Spanish agriculture and the lack of a more rapid industrialisation (Nadal 1975; Tortella 2000 ${ }^{39}$. The image portrayed here regarding the effects of enclosure can therefore be considered as a rather conservative assessment, since the negative consequences coming from a more unequal access to the land on economic development have not been directly addressed.

On the other hand, one of the aims of the privatisation of the commons was to alleviate the finances of the Spanish Crown and reduce the public debt. The General Disentailment Act stipulated that local councils had to be compensated for the loss of these resources. According to the legal text, 20 per cent of the sale value would go directly to the state, while the remaining 80 per cent would belong to the municipalities in the form of perpetual and inalienable public debt yielding a 3 per cent annual return

\footnotetext{
36 The debate on this issue is nonetheless still open (Clark and Clark 2001; Shaw-Taylor 2001).

37 See, for instance, Simón Segura (1973, p. 253), Tomás y Valiente (1978, p. 30), Ortega Santos (2002), and Gallego et al. (2010, pp. 98-99).

38 For recent overviews on these issues, see Acemoglu et al. (2005), Easterly (2007) and Galor (2011).

39 See also Domínguez (2002), Pascual and Sudriá (2002, pp. 214-215), Pinilla (2004, pp. 151-152) and Clar and Pinilla 2009, p. 313).
} 
(Moral Ruiz 1984, pp. 105-106; García Sanz 1985, p. 28). However, not only did these public bonds quickly depreciate, but the state also often failed to honour the outstanding payments (Moral Ruiz 1984, pp. 30-31, 106-107) ${ }^{40}$. As already pointed out, there is ample evidence that municipal finances deteriorated during this period. The provision of local public goods was subsequently negatively affected and the local tax burden increased.

It is true nonetheless that the potential positive effect on the finances of the central state, together with the positive externalities arising from it, have not been considered here. It has been argued, however, that the main reason behind the General Disentailment Act was not a distressing financial background but the political aim of benefiting a small elite (Tomás y Valiente 1978, p. 15). It is also worth stressing that a significant part of the private appropriation of the commons took place by illegal means and, therefore, did not even contribute to the public coffers (Balboa 1999, p. 111; Jiménez Blanco 2002, pp. 148-149). In any case, between 1855 and 1900, the value of the municipal estates that ended up in private hands was 1,120.3 million pesetas. Moral Ruiz (1984, p. 104), however, claims that the amount raised was negligible given that it only represented a small part of what was collected by the lottery revenue. Moreover, the previous figures include the funds obtained from the sale of municipal urban buildings, so they overestimate the amount of money generated by selling common lands.

Notwithstanding the previous arguments, around one third of the funds raised by the Disentailment Act ended up subsidising investments in road and railway infrastructure, and two thirds were devoted to the payment of debt interests and debt amortisation. Given that the railway network was mostly funded with foreign capital, it has been suggested that the contribution so obtained could not have made much difference (Tomás y Valiente 1978, p. 31). Moreover, the disappointing pay-off which the first phase of the building of the railway network yielded casts further doubts on the potentiality of those externalities ${ }^{41}$. The remaining two thirds of the amount collected certainly contributed to reducing the public debt. However, given that the Crown's finances suffered a chronic deficit and the state continued accumulating debt (Tortella 1981, pp. 141-148; Moral Ruiz 1984, pp. 28-31; Comín 1988, p. 414; Fontana 1991, pp. 104-105), the importance of this positive effect remains uncertain. Although more research on these issues is needed, we can tentatively agree with Gabriel Tortella that the disentailment, as a fiscal policy, did not constitute the panacea that was heralded

40 The members of Parliament enacting the Disentailment Act were perfectly aware of the uncertain reliability of those pieces of paper (Simón Segura 1973, pp. 170-178).

41 In this issue, see Fontana (1973, p. 176), Nadal (1975, p. 50), Tortella (1975, pp. 183-200, 274-292) or Comín (1983). The railway mania of the period 1855-1866 and the subsequent excess capacity resulted in the financial panic of 1866, which badly affected the immature Spanish financial system. The economic impact of the establishment of the railway network in Spain has recently been revisited by Herranz (2004). 
(Tortella 1981, p. 139). According to Francisco Comín (1988, p. 43), given the large volume of public debt in circulation compared with the value of the disentailed property, it was indeed naïve to expect that this reform was going to solve the problems of the Treasury.

In addition, it can be argued that the positive effect of the disentailment on the state's financial capacity was more than offset by the consequences of the vast amount of land that flooded the market. On the one hand, the massive purchase of land under the Disentailment Act is likely to have prevented capital from being directed to more productive sectors (Nadal 1975, p. 83; Tortella 1975 , p. 224) ${ }^{42}$. Instead of investing in manufacturing activities or transport infrastructures, financial resources were diverted into purchasing land. On the other hand, the main obstacle hindering the modernisation of the Spanish agricultural sector was the relative prices of the productive factors (Pinilla 2004, p. 150). Owing to the relative factor endowments, capital was dear and land and labour cheap. Farmers subsequently preferred to expand arable land and resort to wage labour than invest in artificial fertilisers or machinery. The massive increase in land supply due to the disentailment undoubtedly prevented land prices from increasing, reinforcing farmers' preferences to cheaply expand the land under cultivation, even running into diminishing returns ${ }^{43}$. Likewise, the privatisation of the commons made peasants dependent on wage labour (Jiménez Blanco 2002, p. 146) ${ }^{44}$, thus pushing salaries downwards. Furthermore, the unequal distribution of land, strengthened by the Madoz Act (1855), created extreme asymmetries in the labour and land markets, thus reinforcing a system of incentives that allowed landowners to maximise their rents without modernising their farms (Pascual and Sudriá 2002, pp. 214-215; Pinilla 2004, p. 151).

\section{VI}

The absences described above therefore do not cloud the image portrayed in this article, which can be safely considered as a rather conservative evaluation of the negative consequences of the privatisation of common lands in $19^{\text {th }}$-century Spain. The way the dismantling of the commons was carried out did not foster agricultural productivity growth and did not solve the financial problems of the Treasury either. Instead, it negatively affected

42 See also Giral i Raventós (1968, pp. 387-388), Tomás y Valiente (1974, p. 135) and Simón Segura 1973, p. 300).

43 Not to mention the fact that land was not only regarded as a safe asset but also as a status good. A great deal of the purchases were made with this in mind rather than with the aim of improving agricultural methods. The complaints about absent landowners are commonplace in Spanish historiography and it has often been argued that the Spanish bourgeoisie invested in land in order to resemble the nobility. See Artola et al. (1978), Bernal (1988) and Saguer (1998).

44 See also López Estudillo (1992, p. 93), GEHR (1999, pp. 130-131) and Ortega Santos (2002, p. 21). 
the economic situation of a large proportion of rural households and local councils, as well as deteriorating the glue that held the community together. In any case, a more accurate assessment of these issues requires new research efforts. In this sense, overcoming the lack of data on the stock of common lands at the end of the $18^{\text {th }}$ century should constitute a priority that would fundamentally advance our understanding of the "forgotten» disentailment of the first half of the $19^{\text {th }}$ century. Likewise, some of the results presented here rely on provincial averages; this hides some of the variation within those regions and also yields a relatively small number of observations, thus limiting the power of the analysis. A more fine-grain investigation, going down to more disaggregated levels of analysis, would surely address such concerns and provide a more detailed picture of how the different mechanisms at play worked at the local level. Not only is a more accurate evaluation of our recent past at stake, but given that developing countries are also facing massive privatisations of natural resources (Ostrom et al. 2002) ${ }^{45}$, a proper understanding of how past societies faced similar challenges would improve our ability to deal with these processes today.

\section{REFERENCES}

Acemoglu, D.; Johnson, S., and Robinson, J. A. (2005): «Institutions as the Fundamental Cause of Long-Run Growth", in P. Aghion, and S. N. Durlauf (eds), Handbook of Economic Growth. vol. IA. Amsterdam: Elsevier, pp. 385-472.

Alchian, A., and Demsetz, H. (1973): «The Property Right Paradigm». Journal of Economic History 33 (1), pp. 16-27.

Allen, R. C. (1982): «The Efficiency and Distributional Consequences of Eighteenth Century Enclosures». The Economic Journal 92 (368), pp. 937-953.

Allen, R. C. (1992): Enclosures and the Yeomen. Oxford: Oxford University Press.

Allen, R. C. (1999): «Tracking the Agricultural Revolution». Economic History Review 52, pp. 209-235.

Allen, R. C. (2001): "Community and Market in England: Open Fields and Enclosures Revisited», in M. Aoki, and Y. Hayami (eds), Communities and Markets in Economic Development. Oxford: Oxford University Press, pp. 42-69.

Allen, R. C. (2003): «Progress and Poverty in Early Modern Europe». Economic History Review 56 (3), pp. 403-443.

Allen, R. C., and O'Grada, C. (1988): «On the Road Again with Arthur Young: English, Irish, and French Agriculture During the Industrial Revolution». Journal of Economic History 48 (1), pp. 93-116.

Artiaga, A., and Balboa, X. (1992): «La Individualización de la Propiedad Colectiva: Aproximación e Interpretación del Proceso en los Montes Vecinales de Galicia». Agricultura y Sociedad 65, 101-120.

Artola, M.; Bernal, A. M., and Contreras, J. (1978): El latifundio. Propiedad y Explotación, s. XVIII-XX. Madrid: Servicio de Publicaciones Agrarias.

45 The commons nowadays actually constitute a much wider category than that analysed here. See also Dolsak and Ostrom (2003) and Bravo and De Moor (2008). 
Baland, J.-M., and Platteau, J.-P. (1998): «Division of the Commons: A Partial Assessment of the New Institutional Economics of Land rights». American Journal of Agricultural Economics 80 (3), 644-650.

Baland, J.-M., and Platteau, J.-P. (2003): «Economics of Common Property Management Regimes», in K. -G. Maler, and J. R. Vicent (eds), Handbook of Environmental Economics. vol. 1. Amsterdam: Elsevier, pp. 127-190.

Balboa, X. L. (1999): «La Historia de los Montes Públicos Españoles (1812-1936): Un Balance y Algunas Propuestas». Historia Agraria 18, pp. 95-128.

Balboa, X. L., and Fernández Prieto, L. (1996): «Evolución de las Formas de Fertilización en la Agricultura Atlántica Entre los Siglos XIX y XX. Del toxo a los Fosfatos», in R. Garrabou, and J. M. Naredo (eds), La Fertilización en Los Sistemas Agrarios. Una Perspectiva Histórica. Madrid: Fundación Argentaria, pp. 211-235.

Behar, R. (1986): Santa María del Monte. The Presence of the Past in a Spanish Village. Princeton: Princeton University Press.

Beltrán Tapia, F. J. (2012): «Commons, Social Capital and the Emergence of Agricultural Cooperatives in Early 20th Century Spain». European Review of Economic History 16, pp. 511-528.

Beltrán Tapia, F. J. (2013): «Enclosing Literacy? Common Lands and Human Capital in Spain, 1860-1930». Journal of Institutional Economics 9 (4), pp. 491-515.

Beltrán Tapia, F. J. (2015a): «Social and Environmental Filters to Market Incentives: Common Land Persistence in $19^{\text {th }}$ Century Spain». Journal of Agrarian Change 15 (2), pp. 239-260.

Beltrán TAPiA, F. J. (2015b): «Common Lands and the Standard of Living Debate in Spain, 1860-1930». Cliometrica 9 (1), pp. 27-48.

Beltrán TaPia, F. J. (2015c): «'Goths and Vandals' or 'Civilised’ Farmers? Common Lands and Agricultural Productivity in Early Twentieth Century Spain». Social Science History 39 (2), pp. 217-252.

Bernal, A. M. (1978): «Haciendas Locales y Tierras de Propios: Funcionalidad Económica de los Patrimonios Municipales (siglos XVI-XIX)». Hacienda Pública Española 55, pp. 285-312.

Bernal, A. M. (1988): Economía e Historia de los Latifundios. Madrid: Espasa-Calpe.

Besley, T., and Ghatak, M. (2009): «Property Rights and Economic Development», in D. Rodrik, and M. Rosenzweig (eds), Handbook of Development Economics. Amsterdam: Elsevier, pp. 4525-4595.

Bhaduri, A. (1986): «Forced Commerce and Agrarian Growth». World Development 14 (2), pp. 267-272.

Bhaduri, A. (1991): «Economic Power and Productive Efficiency in Traditional Agriculture», in B. Gustafsson (ed.), Power and Economic Institutions. Reinterpretations in Economic History. Aldershot: Edward Elgar, pp. 53-68.

Bravo, G., and De Moor, M. (2008): «The Commons in Europe: From Past to Future». International Journal of the Commons 2 (2), pp. 155-161.

Caballero, F. (1864): Fomento de la Población Rural. Madrid: Imprenta Nacional.

CARmona, J., and Simpson, J. (2003): El Laberinto de la Agricultura Española. Instituciones, Contratos y Organización Entre 1850 y 1936. Zaragoza: Prensas Universitarias.

Carrión, P. (1932): Los Latifundios en España: Su Importancia, Origen, Consecuencias y Solución. Madrid: Gráficas Reunidas.

Cendrero, V. (2014): «¿Privatización o Expolio? La Desamortización del Monte Público en Almodóvar del Campo, Ciudad Real (1845-1897)». Historia Agraria 63, pp. 89-114.

Chambers, J. D., and Mingay, G. E. (1966): The Agricultural Revolution, 1750-1880. London: Batsford. 
Chang, H.-J. (2011): «Institutions and Economic Development: Theory, Policy and History». Journal of Institutional Economics 7, pp. 473-498.

Clar, E., and Pinilla, V. (2009): "The Contribution of Agriculture to Spanish Economic Development», in P. Lains, and V. Pinilla (eds), Agriculture and Economic Development in Europe Since 1870. London: Routledge, pp. 251-269.

Clark, G. (1998): "Commons Sense: Common Property Rights, Efficiency, and Institutional Change». Journal of Economic History 48, pp. 73-102.

Clark, G., and Clark, A. (2001): "Common Rights to Land in England, 1475-1839». Journal of Economic History 61 (4), pp. 1009-1036.

Cole, D. H., and Ostrom, E. (2011): "The Variety of Property Systems and Rights in Natural Resources», in D. H. Cole, and E. Ostrom (eds), Property in Land and Other Resources. Cambridge, MA: Lincoln Institute of Land Policy, pp. 37-64.

Comín, F. (1983): "Comentarios en Torno al Ferrocarril y Crecimiento Económico Español Entre 1855 y 1913». Revista de Historia Económica 19, pp. 125-137.

Сомín, F. (1988): Hacienda y Economía en la España Contemporánea, 1800-1936. Madrid: Ministerio de Hacienda.

Comín, F. (1996): Historia de la Hacienda Pública, vol. II, España, 1808-1995. Barcelona: Crítica.

Comín, F., and Yun-Casalilla, B. (2012): «Spain: From Composite Monarchy to Nation State, 1492-1914. An Exceptional Case?», in B. Yun-Casalilla, P. O'Brien, and F. Comín (eds), The Rise of Fiscal States. A Global History, 1500-1914. Cambridge: Cambridge University Press, pp. 233-266.

Costa, J. (1898): Colectivismo Agrario en España. Madrid: Imprenta de San Francisco de Sales.

Curto-Grau, M.; Herranz-Loncán, A., and Solé-Ollé, A. (2012): «Pork-Barrel Politics in Semi-Democracies: The Spanish 'Parliamentary Roads'». Journal of Economic History 72 (3), pp. 771-796.

Demélas, M.-D., and Vivier, N. (2003): Les Propriétés Collectives Face aux Ataques Libérales, 1750-1914: Europe Occidentale et Amérique Latine. Rennes: Presses Universitaires de Rennes.

de Jovellanos, M. G. (1795): Informe de la Sociedad Económica de esta Corte al Real y Supremo Consejo de Castilla en el Expediente de Ley Agraria. Madrid: Imprenta de Sancha.

DE Moor, M. (2009): «Avoiding Tragedies: A Flemish Common and its Commoners Under the Pressure of Social and Economic Change during the Eighteenth Century». Economic History Review 62 (1), pp. 1-22.

DE Moor, M.; SHAw-TAYLOR, L., and WARDE, P. (eds) (2002): The Management of Common Land in North West Europe, ca. 1500-1850. Brepols: Turnhout.

Dolsak, N., and Ostrom, E. (eds) (2003): Commons in the New Millennium: Challenges and Adaptation. Cambridge, MA: MIT Press.

Domínguez, R. (2002): «Desigualdades Sociales y Crecimiento Económico Regional en España a largo Plazo». Revista de Historia Industrial 22, pp. 177-193.

EAsterly, W. (2007): "Inequality Does Cause Underdevelopment: Insights from a New Instrument». Journal of Development Economics 84 (2), pp. 755-776.

EnRLe, L. (1961): English Farming. Past and Present. London: Heinemann.

Feeny, D.; Berkes, F.; McCay, B. J., and Acheson, J. M. (1990): "The Tragedy of the Commons: Twenty-Two Years Later». Human Ecology 18 (1), pp. 1-19.

Fenske, J. (2014): "Imachi Nkwu: Trade and the Commons». Journal of Economic History 74 (1), pp. 39-68.

Floud, R., and Johnson, P. (2004): The Cambridge Economic History of Modern Britain: Volume 1 - Industrialisation, 1700-1860. Cambridge: Cambridge University Press. 
Fontana, J. (1973): Cambio Económico y Actitudes Políticas en la España del Siglo XIX. Barcelona: Ariel.

Fontana, J. (1991): «Deuda Pública, Evolución de la Hacienda y Crecimiento Económico. Algunas Sugerencias Para su Estudio», in F. Comín, and J. Zafra (eds), Historia de la Hacienda en España (siglos XIX y XX). Homenaje a D. Felipe Ruiz Martín. Madrid: Instituto de Estudios Fiscales, pp. 101-1056.

Gallego, D. (2007): Más allá de la Economía de Mercado: los Condicionantes Históricos del Desarrollo Económico. Madrid: Marcial Pons.

Gallego, D.; Iriarte, I., and Lana, J. M. (2010): «Las Españas Rurales y el Estado, 18001931», in R. Robledo (ed.), Las Sombras del Progreso. Las Huellas de la Historia Agraria. Barcelona: Crítica, pp. 85-116.

Galor, O. (2011): «Inequality, Human Capital Formation, and the Process of Development», in E. A. Hanushek, S. J. Machin, and L. Woessmann (eds), Handbook of the Economics of Education. vol. 4. Amsterdam: Elsevier, pp. 441-493.

García, C., and Comín, F. (1995): «Reforma Liberal, Centralismo y Haciendas Municipales en el Siglo XIX». Hacienda Pública Española 133, pp. 81-106.

García SANZ, A. (1985): «Introducción», in A. García Sanz, and R. Garrabou (eds), Historia Agraria de la España Contemporánea. vol. 1. Barcelona: Crítica, pp. 7-99.

GEHR (1994): «Más allá de la 'Propiedad Perfecta'. El Proceso de Privatización de los Montes Públicos Españoles (1859-1926)». Noticiario de Historia Agraria 8, pp. 99-152.

GEHR (1999): «Diversidad Dentro de un Orden. Privatización, Producción Forestal y Represión en los Montes Públicos Españoles, 1859-1926». Historia Agraria 18, pp. 129-178.

GiRAL I Raventós, E. (1968): «Problemas Históricos de la Industrialización Valenciana». Estudios Geográficos 112, pp. 369-395.

Gómez Urdañez, G. (2002): «Doctrinas y Realidades. Los Frenos a la Liberalización de la Propiedad en España, 1835-1855». Historia Agraria 27, pp. 133-163.

González De Molina, M.; Infante Amate, J., and Herrera González De Molina, A. (2014): "Cuestionando Los Relatos Tradicionales: Desigualdad, Cambio Liberal y Crecimiento Agrario en el Sur Peninsular (1752-1901)». Historia Agraria 63, pp. 55-88.

Guzmán, G. I., and González De Molina, M. (2006): Tras los Pasos de la Insustentabilidad. Agricultura y Medioambiente en Perspectiva Histórica. Barcelona: Icaria.

Hardin, G. (1968): «The Tragedy of the Commons». Science 1628, pp. 1243-1248.

Herr, R. (1974): «El Significado de la Desamortización en España». Moneda y Crédito 131, pp. $55-94$.

Herranz, A. (2004): «Infrastructure and Economic Growth in Spain, 1845-1935». Journal of Economic History 64 (2), pp. 540-545.

Humphries, J. (1990): «Enclosures, Common Rights, and Women: The Proletarisation of Families in the Late Eighteenth and Early Nineteenth Centuries». Journal of Economic History 50 (1), pp. 17-42.

Iriarte, I. (1998): «La Pervivencia de Bienes Comunales y la teoría de los Derechos de Propiedad. Algunas Reflexiones desde el Caso Navarro, 1855-1935». Historia Agraria 15, pp. 113-142.

Iriarte, I. (2002): «Common Lands in Spain, 1800-1995: Persistence, Change and Adaptation». Rural History 13 (1), pp. 19-37.

IRIARTE, I. (2003): «Algunos Modelos de Explotación Forestal: Ingresos de Montes y Haciendas Municipales en el norte de Navarra (1867-1935)», in J. A. Sebastián, and R. Uriarte (eds), Historia y Economía del Bosque en la Europa del sur, Siglos XVIII-XX. Zaragoza: Prensas Universitarias de Zaragoza, pp. 225-255. 
Jiménez Blanco, J. I. (2002): «El Monte: Una Atalaya de la Historia». Historia Agraria 26, pp. 141-190.

Lana, J. M. (2008): «From Equilibrium to Equity. The Survival of the Commons in the Ebro Basin: Navarra from the $15^{\text {th }}$ to the $20^{\text {th }}$ Centuries». International Journal of the Commons 2 (2), pp. 162-191.

Lana, J. M. (2014): “Esta Especie de Socialismo Campesino... Manso y Tranquilo’. Un Estado de la Cuestión desde la Historia Rural Española». Revista Mexicana de Sociología 76, pp. 167-197.

Linares, A. M. (1995): «De la Apropiación del Usufructo a la Privatización de la Superficie. Las Tierras Concejiles en la Baja Extremadura (1750-1850)». Noticiario de Historia Agraria 9, pp. 87-127.

Linares, A. M. (2001): «Estado, Comunidad y Mercado en los Montes Municipales Extremeños (1855-1924)». Revista de Historia Económica 19 (1), pp. 17-52.

Linares, A. M. (2006): «Tapando Grietas: Hacienda Local y Reforma Tributaria en Extremadura (1750-1936)». Investigaciones de Historia Económica 5, pp. 71-104.

López Estudillo, A. (1992): «Los Montes Públicos y las Diversas vías de su Privatización en el Siglo XIX». Agricultura y Sociedad 65, pp. 65-99.

Malefakis, E. E. (1970): Agrarian Reform and Peasant Revolution in Spain: Origins of the Civil War. New Haven: Yale University Press.

Mangas Navas, J. M. (1981): El Regimen Comunal Agrario de los Concejos de Castilla. Madrid: Ministerio de Agricultura.

Moral RuIz, Del J. (1979): La Agricultura Española a Mediados del Siglo XIX (1850-70): Resultados de una Encuesta Agraria de la Época. Madrid: Servicio de Publicaciones Agrarias.

Moral Ruiz, del J. (1984): Hacienda Central y Haciendas Locales en España, 1845-1905. Madrid: Instituto de Estudios de Administración Local.

Moreno, J. R. (1998): «El Régimen Comunal y la Reproducción de la Comunidad Campesina en las Sierras de La Rioja (siglos XVIII-XIX)». Historia Agraria 15, pp. 75-111.

Moreno, J. R. (2002): «La lógica del Comunal en Castilla en la edad Moderna: Avances y Retrocesos de la Propiedad Común», in S. de Dios, J. Infante, R. Robledo, and E. Torijano (eds), Historia de la Propiedad en España. Bienes Comunales, Pasado y Presente. Salamanca: Colegio de Registradores, pp. 139-178.

Moreno Luzón, J. (2007): «Political Clientelism, Elites, and Caciquismo in Restoration Spain (1875-1923)». European History Quarterly 37 (3), pp. 417-441.

NADAL, J. (1975): El Fracaso de la Revolución Industrial en España, 1814-1913. Barcelona: Ariel.

NeEson, J. M. (1993): Commoners: Common Right, Enclosure and Social Change in England, 1700-1820. Cambridge: Cambridge University Press.

Nieto, A. (1964): Bienes Comunales. Madrid: Revista de Derecho Privado.

North, D. C., and Thomas, R. P. (1978): «The First Economic Revolution». Economic History Review 30, pp. 229-241.

OgILvie, S. (2007): "Whatever is, is Right'? Economic Institutions in Pre-Industrial Europe». Economic History Review 60, pp. 649-684.

Ortega Santos, A. (2002): La Tragedia de los Cerramientos. Valencia: Fundación Instituto de Historia Social.

Ostrom, E. (1990): Governing the Commons, the Evolution of Institutions for Collective Action. Cambridge: Cambridge University Press.

Ostrom, E. (2005): Understanding Institutional Diversity. Princeton: Princeton University Press. 
Ostrom, E. (2010): «Beyond Markets and States: Polycentric Governance of Complex Economic Systems». American Economic Review 100 (3), pp. 641-672.

Ostrom, E.; Dietz, T.; Dolsak, N.; Stern, P. C.; Stonich, S., and Weber, E. U. (2002): The Drama of the Commons. Washington: National Academy Press.

Pascual, P., and Sudriá, C. (2002): «Notas Sobre El Pozo...». Historia Agraria 28, pp. 207-216.

Pereda, J. M. ([1895] 1999): Peñas Arriba. Madrid: Espasa-Calpe.

Pinilla, V. (2004): "Sobre la Agricultura y el Crecimiento Económico en España (1800-1935)». Historia Agraria 34, pp. 137-162.

PolanyI, K. (2001): The Great Transformation: The Political and Economic Origins of Our Time. Boston: Beacon Press.

Pujol, J.; González De Molina, M.; Fernández Prieto, L.; Gallego, D., and Garrabou, R. (2001): El Pozo de todos los Males. Sobre el Atraso en la Agricultura Española Contemporánea. Barcelona: Crítica.

Robledo, R. (1993): Economistas y Reformadores Españoles: la Cuestión Agraria, 17601935. Madrid: MAPA.

Rueda, G. (1997): La Desamortización en España: Un Balance, 1766-1924. Madrid: Arco.

Runge, C. F. (1986): «Common Property and Collective Action in Economic Development». World Development 14 (5), 623-635.

SAGUer, E. (1998): «Estímulos y Obstáculos al Avance de la Propiedad Campesina (El Baix Empordà, 1860-1940)». Revista de Historia Económica 3, pp. 677-706.

SANZ Fernández, J. (1985): «La Historia Contemporánea de los Montes Públicos Españoles, 1812-1930. Notas y Reflexiones (I)», in R. Garrabou, and J. Sanz (eds), Historia Agraria de la España Contemporánea. vol. 2. Barcelona: Crítica, pp. 193-228.

Sanz Fernández, J. (1986): "La Historia Contemporánea de los Montes Públicos Españoles, 1812-1930. Notas y Reflexiones (II)», in R. Garrabou, C. Barciela, and J. I. Jiménez Blanco (eds), Historia Agraria de la España Contemporánea. vol. 3. Barcelona: Crítica, pp. 142-170.

Serrano, J. A. (2005): "La Defensa del Comunal y de los Usos Colectivos, León (1800-1936): ¿una 'Economía Moral'?». Historia Agraria 37, pp. 431-463.

Serrano, J. A. (2014): "When the Enemy is the State: Common Lands Management in Northwest Spain (1850-1936)». International Journal of the Commons 8 (1), pp. 107-133.

SHAW-TAYLOR, L. (2001): «Parliamentary Enclosure and the Emergence of an English Agricultural Proletariat». Journal of Economic History 61 (3), pp. 640-662.

Silvestre, J. (2005): «Internal Migrations in Spain, 1877-1930». European Review of Economic History 9, pp. 233-265.

Simón Segura, F. (1973): La Desamortización Española en el Siglo XIX. Madrid: Instituto de Estudios Fiscales.

Simpson, J. (1995): Spanish Agriculture: The Long Siesta, 1765-1965. Cambridge: Cambridge University Press.

Timmer, C. P. (2002): «Agriculture and Economic Development», in B. Gardner, and G. Rausser (eds), Handbook of Agricultural Economics. Amsterdam: Elsevier, pp. 1487-1546.

Tomás Y. Valiente, F. (1974): «Recientes Investigaciones Sobre la Desamortización: Intento de Síntesis». Moneda y Crédito 131, pp. 95-160.

Tomás Y Valiente, F. (1978): «El Proceso de Desamortización de la Tierra en España». Agricultura y Sociedad 7, pp. 11-33.

Tortella, G. (1975): Los orígenes del Capitalismo en España. Banca, Industria y Ferrocarriles en el Siglo XIX. Madrid: Tecnos. 
Tortella, G. (1981): «La Economía Española, 1830-1900», in M. Tuñón de Lara (ed.), Historia de España. Revolución Burguesa, Oligarquía y Constitucionalismo. vol. 8. Barcelona: Labor, pp. 11-167.

Tortella, G. (2000): The Development of Modern Spain. An Economic History of the Nineteenth and Twentieth Centuries. Cambridge, MA: Harvard University Press.

VAN Zanden, J. L. (1999): «The Paradox of the Marks. The Exploitation of Commons in the Eastern Netherlands, 1250-1850». Agricultural History Review 47 (2), pp. 125-144.

WADE, R. (1994): Village Republics: Economic Conditions for Collective Action in South India. San Francisco: ICS Press. 